Utah State University

DigitalCommons@USU

$\mathrm{Ca}$

Bee Lab

$12-1-1897$

\title{
LX.- New Insects from Embudo, New Mexico
}

T. D. A. Cockerell

New Mexico Agricultural Experientment Station

Follow this and additional works at: https://digitalcommons.usu.edu/bee_lab_ca

\section{Recommended Citation}

Cockerell, T. D. A., "LX.- New Insects from Embudo, New Mexico" (1897). Ca. Paper 212.

https://digitalcommons.usu.edu/bee_lab_ca/212

This Article is brought to you for free and open access by the Bee Lab at DigitalCommons@USU. It has been

accepted for inclusion in $\mathrm{Ca}$ by an authorized administrator of DigitalCommons@USU. For more

information, please contact digitalcommons@usu.edu.

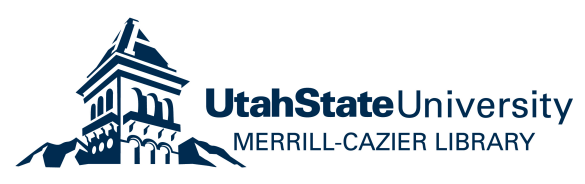


From the Annals and Magagine of Taturac Hestory, Ser. 6, Voe. $x x$, Decombere, 1897

Clcll 1897 
ment of the coxa, trochanter, and femur strongly suggestive of that pointed out by me in the case of the Phasmidæ in my communication to the Académie des Sciences of February 15, 1897 *. I was particularly struck with this on examining: the last figure referred to, which, however, represents an insect much more nearly allied to the Neuroptera than to the Orthoptera, since M. Ch. Brongniart has assigned it to the former.

Messrs. Bateson and Brindley, after mentioning numerous instances of tetramery in Blattidæ, conclude that they are to be regarded as cases of abrupt variation ("variation brusque"), explaining up to a certain point how a species with tetramerous tarsi might be derived, abruptly so to speak, from a species with pentamerous tarsi ("Materials for the Study of Variation,' 1894, pp. 63 and 415-421). A philosophical explanation appears to me much more logical: this consists in regarding, on the contrary, these interesting facts as cases of atavism, of reversion to an ancestral condition similar to that still to be observed in the Locustidæ $\dagger$.

LX.-New Insects from Embudo, New Mexico. By T. D. A. Cockereld, Entomologist of the New Mexico Agricultural Experiment Station.

As we ascend the Rio Grande the fauna and flora gradually change, southern types giving place to others of a boreal or sub-boreal character. The detailed study of the distribution of species up and down the banks of the river presents much to attract the zoologist or botanist, and the briefest investigations are repaid by new and interesting results. The present writer had recently an opportunity of spending a couple of days at Embudo, situated on the Rio Grande in northern New Mexico, about 300 miles north of Mesilla. This locality is in a district never explored by entomologists, and it was to be expected that new forms would be found. These expectations were not disappointed, and descriptions of the novelties are herewith presented.

\section{Apidæ.}

At the flowers of Bigelovia four species of Perdita occurred, three of them in considerable numbers. They were as follows:-

* Tide suprà, p. 476: "Phenomena of Autotomy in Phasmidæ belonging to the Genera Monandroptera and Rhaphiderus."

" † Cf. A. Giard, 'Comptes Rendus de la Société de Biologie,' 1897, по. 12, p. 315 . 


\section{(1) Perdita Townsendi, Ckll.}

Both sexes, Sept. 25 and 26. Known before only from the White Sands.

(2) Perdita affinis, Cress.

Known before only from Colorado. Many taken, Sept. 26.

(3) Perdita rhodura, sp. n.

o.- - Length hardly 6 millim.

Head and thorax dark olive-green, moderately hairy, face not hairy; abdomen banded. Head ordinary, front strongly granular ; antennæ dark brown, stripe on scape and flagellum beneath dull yellowish or ochraceous; labrum, mandibles (except tips), and face-marks white; sides of clypeus with large shallow punctures; lower half of clypeus white, the white extending upwards in three tooth-like projections, the lateral ones having the clypeal dots at their base; the upper outline of the white on the clypeus is that of a W; lateral face-marks broad below, gradually tapering to a blunt point opposite the upper edges of the antennal sockets. 'Tubercles white at ends; mesothorax granular and sparsely punctured; tegulæ hyaline, with a dull white spot; wings hyaline, iridescent; nervures dark brown, stigma hyaline except margin, poststigmatal portion of marginal cell a little longer than substigmatal, second submarginal large, narrowed more than half to marginal, third discoidal distinct. Legs black; trochanters, knees, anterior and middle tibiæ in front, and anterior tarsi light yellow or yellowish white. Abdomen above with segments 1 to 3 white, 4 and 5 brownish orange; segments 1 to 3 with piceous bands at base and hind margin, 4 with similar but more suffused banding. Venter dull yellowish, becoming orange at apex.

o.- - Length 5 millim.

Antennæ bright lemon-yellow, funicle and flagellum (except last two segments) largely piceous above; face all bright lemon-yellow up to the level of the length of the scape above insertion of antennæ, the yellow including the anteorbital black spots; labrum and mandibles (except extreme tips) lemon-yellow; prothorax (except two spots anteriorly and quadrate patch on pleura) yellow; legs yellow, hind tibir behind and hind tarsi piceous ; abdomen with the first segment piceous at base, but no well-defined bands, only suffused ones along hind margins of 1 and 2.

Hab. Embudo, Sept. 25. Many specimens. 
P. rhodura + runs in my table of Perdita (Proc. Phil. Acad. 1896) to 71 , and is separated from $P$. Snowii by the pallid venter, marking of clypeus, \&c. It most resembles $P$. crotonis, especially in the colour of the abdomen, but differs at once by the face-markings, granular mesothorax, \&c. $P$. rhodura or runs in the table to 12 , but is quite distinct from $P$. chamasarachoe, to which it comes nearest.

\section{(4) Perdita subfasciata, sp. n.}

f.-Length about 5 millim.

Thorax small; head and thorax very dark bluish green, almost black; front microscopically tessellate and sparsely punctured; face wholly dark; clypeus black, with strong sparse punctures, wanting in the middle; labrum and mandibles wholly dark; antennæ piceous, flagellum light brown beneath. Prothorax and tubereles wholly dark; mesothorax microscopically tessellate and sparsely punctured, median and parapsidal grooves distinet; tegulæ hyaline, with a white spot at anterior base. Wings hyaline; nervures colourless, except the subcostal, margins of stigma, and of marginal cell, which are brown; marginal cell with substigmatal portion noticeably longer than poststigmatal; second submarginal narrowed scarcely half to marginal; third discoidal present. Legs black, first four tarsi, anterior tibiæ in front, and anterior knees dull yellow. Abdomen above brown-black, segments 3 to 5 each with a broad, straight, subbasal band of dull yellow, abruptly terminating some distance before the lateral margin. Venter piceous.

Hab. Embudo, Sept. 25. One.

P. subfasciata runs in my table of Perdita $(l . c$.) to 19 , but is quite different from $P$. mentzelice. It is not unlike $P$. cenez-frons, but differs at once by the bands on the abdomen \&c.

The only other Perdita taken at Embudo was P. zebrata, Cress., one at flowers of Cleome serrulata, Sept. 26.

\section{Andrenidæ.}

Andrena vulpicolor, sp. $\mathrm{n}$.

o.-Length about 15 millim.

Black, with fox-red pubescence. Head of ordinary form; antennæ black; face rather thinly clothed with orange hair; cheeks densely clothed with orange and occiput with bright rufous hair. Process of labrum truncate, very large and broad; clypeus granular and with large punctures; sides of 
face smoother and more shiny, but still granular, with rather sparse punctures; front roughened. Pubescence of thorax dense, orange beneath, fox-red above ; a large part of mesothorax and middle of scutellum practically nude, as also the metathoracic enclosure, which is dull and not bounded by any raised line. Mesothorax regularly and strongly granular; scutellum granular, with shallow punctures. Tegulæ transparent amber-colour. Anterior wings rather pale fuliginous, broadly darker on outer margin, largely hyaline in median and anal cells; nervures and stigma piceous, stigma rather small; hind wings hyaline, with the basal third fuliginous. Legs black, with orange hairs. Abdomen black, microscopically tessellate, with very sparse inconspicuous shallow punctures; sides of first segment, broad submarginal bands on segments 2 to 4 (on 2 interrupted medially), the fifth segment, and the apex all clothed with foxy-red hair; in addition, the second and third segments have very narrow apical hair-bands, contrasting with the rufous broad hairbands above them. Tibial spurs rufous.

Hab. Embudo, at flowers of Bigelovia, Sept. 25 to 27. Nine specimens.

This fine species seems to be allied to A. obscuripennis, Smith, from Georgia, but it differs from that in the entirely black clypeus, the colour of the legs, and the distinct fasciæ of the abdomen.

\section{Mutillidæ.}

Ephuta californica (Rad.), var. euchroa, n. var.

q.- Similar to the typical form, but the bright pubescence (on dorsal surfaces of head, thorax, and abdomen) all of a beautiful deep crimson or carmine, instead of ferruginous or golden ochraceous.

Hab. Embudo, one on sand by the river, Sept. 25. Also one collected by Prof. H. F. Wickham at Coolidge, N. M., some years ago.

I have seen exactly the same colour of pubescence in an example of Ephuta pacifica (Cresson), collected by Mr. Wickham in California. This insect bears a great resemblance to our variety, but is readily distinguished by its considerably larger head.

The generic name Ephuta has priority over Sphcerophthalma, as has been indicated by Mr. Fox. 


\section{Coccidæ.}

\section{Eriococcus arenosus, sp. n.}

o.- Scale oval, about 4 millim. long, white, covered all over with particles of sand.

9.-Boiled in caustic soda stains the liquid reddish. Legs and antennæ pale brownish; antennæ shorter than tibia + tarsus, 7 -segmented, 4 longest, 3 a little shorter than 1 , then 2, then 5. Formula $43125(67) .4$ about as long as $5+6+7 ; 7$ quite bristly. Legs large; coxa large ; femur hardly a third longer than tibia; tibia and tarsus almost exactly the same length, each with a few stont bristles. Claw large, not much curved; all the digitules filiform, with inconspicuous knobs, that of tarsus extending nearly as far as those of claw. There appears to be only one tarsal digitule. Skin with many round gland-spots and stout blunt spines. Caudal tubercles elongate. $q$ flattened under coverglass $3 \frac{1}{3}$ millim. long, oval,

Eggrs pale lemon-yellow.

3.- Scale small and narrow, yellowish white or snowwhite, not covered with sand.

$H a b$. Embudo, Sept. 26, on a low herbaceous plant with linear conspicuously gland-dotted leaves, not seen in flower*.

The sand-covered sac is a peculiarity of the Coccid.

\section{Lecaniodiaspis artemisia, sp. $\mathrm{n}$.}

ᄋ.- Scale suboval, 3 millim. long, $1 \frac{2}{3}$ wide, reddish ochreous, peppered with black specks; surface dull, rough and tuberculate, thoracic region with two prominent transverse crests.

9.-Dermis with scattered figure-of- 8 glands and small spines. Caudal tubercles quite well developed. Mentum rather obscurely trimerous. Antennæ apparently absent in adult; in younger examples they are small rounded prominences, bristly at end, without visible joints. The insects after boiling are pale pinkish.

o.- Scale about $1 \frac{1}{3}$ millim. long, subcylindrical, creamcolour with black specks. The black specks on the scales consist of extraneous matter attached.

Hab. Embudo, Sept. 25, on sage-brush (Artemisia). A bright red mite occurs among them.

$L$. artemisice is very distinct by the aborted antennæ.

* I sent the plant on which Eriococcus arenosus was found to Prof. E. O. Wooton, who says he thinks it is safe to call it Psoralea micrantha, Gray. 
The other Coccids found at Embudo were Coccus confusus, Ckll. (between Embudo and Rinconada), Dactylopius gutienezice, Ckll. (also at Rinconada), D. Tichtensioides, Ckll. (empty sacs only), Orthezia artemisia, Ckll. ined., and O. nigrocincta, Ckll.

LXI.-Descriptions of further new Species of Butterflies from the Pacific Islands. By H. Grose-Sмiтн, B.A., F.E.S., F.Z.S.

\section{Limenitis chilo.}

Female.-Upperside. Anterior wings chocolate-brown; the disk is crossed beyond the cell by an oblique band of contiguous white spots, divided by the brown veins, and extending from near the costal margin, a little beyond its middle, to near the lowest submedian nervule at one third from the outer margin; a subapical tawny patch and a submarginal narrow sinuate band. Posterior wings with the basal half chocolatebrown and the outer half pale tawny brown, with a rather broad brown outer margin and a submarginal sinuate brown line from the apex to the anal angle.

Underside. Anterior wings with a reniform pale grey bar crossing the cell about its middle and a white streak at the end of the cell, both margined with red-brown, and two reddish-brown spots below the cell towards the base, the lower smaller than the upper spot; the oblique white discal band extends nearer to the margin and outer angle than on the upperside. Posterior wings with a subovate red-brown ring towards the base below the costal nervure, and several red-brown markings in the cell; two red-brown bars cross the wings, one before, the other beyond the middle; the outer tawny space of the upperside is represented by a pale pinkishbrown area, the submarginal brown line, as on the upperside, edged externally by whitish brown.

Exp. of wings $1 \frac{7}{8}$ inch.

Hab. Sumba, below 2000 feet (Doherty).

In the collection of the Hon. Walter Rothschild. A single specimen only, in a battered condition.

\section{Hypocista calypso.}

Male.-Upperside. Differs from H. osyris, Boisd., in the more restricted area of the pale tawny patch on the posterior wings, which is confined to the outer two thirds of the cell 
